\title{
Papel do professor-tutor como mediador no processo de formação profissional
}

\author{
Lucas Cardoso dos Santos, Janete Pessuto Simonetti, Antonio de Pádua Pithon Cyrino
}

\section{Resumo}

O papel do professor-tutor como mediador no processo de formação profissional Introdução Na última década, fez-se um grande esforço, no âmbito das graduações de profissões da saúde, para reorientar a formação de modo a melhor atender às necessidades do Sistema Único de Saúde, com importante influência das Diretrizes Curriculares Nacionais das profissões da saúde e do papel indutivo realizado pelos Ministérios da Saúde e Educação para se alcançar uma formação mais humanizada e desenvolvida mediante processo de ensino-aprendizagem em diferentes cenários e com práticas de interprofissionalidade. A educação interprofissional tem sido apontada como capaz de promover mudanças nos cenários de ensino, buscando práticas eficientes para o enfrentamento da complexidade dos problemas de saúde. E vem sendo, cada vez mais, valorizada dado o seu potencial na formação de profissionais de saúde mais preparados para o trabalho em equipe, característica essencial para se alcançar um cuidado integral de indivíduos, famílias e comunidades. Nesta perspectiva, o objetivo deste estudo foi compreender a percepção e a vivência de educação interprofissional, nas disciplinas de Interação Universidade, Serviços e Comunidade I e II, entre discentes dos cursos de Medicina e Enfermagem da Faculdade de Medicina de Botucatu. Método Realizou-se pesquisa de natureza qualitativa, que teve a entrevista semiestruturada como instrumento de coleta de dados. A organização e análise dos dados empregada foi orientada segundo a Análise Temática de Conteúdo proposto por Bardin. Como resultados, emergiram três categorias temáticas: A experiência de Educação interprofissional permite que o aluno compreenda melhor o colega do outro curso; Aprender sobre o outro traz benefícios para a formação profissional; O papel do professor-tutor como mediador no processo de formação profissional. A seguir apresentar-se-á os resultados relacionados a essa última categoria temática. Fizeram parte deste estudo dez alunos dos cursos de medicina e enfermagem que vivenciaram a educação interprofissional nas disciplinas referidas, sendo três do sexo masculino e sete do sexo feminino, cinco de cada um dos cursos de graduação, cujas idades variaram entre 19 e 30 anos. Foram atribuídos nomes fictícios e alterada ou suprimida qualquer informação que pudesse identificar os discentes. A letra após os diálogos tem a intenção de identificar de qual curso é o aluno: E (enfermagem) ou M (medicina). Resultados Parte dos discentes apontaram que aprender com um professor-tutor de formação diferente da sua limita o seu aprendizado e por isso aprenderam menos sobre assuntos específicos da sua profissão. Tal percepção vai ao encontro da formação profissional hegemônica nos cursos da saúde e que se distancia da prática interprofissional: Eu acho que talvez fique defasado, como a gente trabalha muito com assistência de enfermagem, cuidado de enfermagem e tudo mais, eu acho que talvez por esse lado fique faltando e poderia ser complementado (Graziella E). Por outro lado, alguns alunos reconheceram que aprender com um professor-tutor com uma formação diferente da sua foi positivo, valorizando tal proposta pedagógica: Eu achei melhor ter um tutor que não fosse médico, porque eu acho que a gente vai ter essa experiência só depois [...] achei que foi importante eles trazerem umas coisas diferentes, informações diferentes por outros caminhos que eu acho que não teria sido feito por alguém que fosse médico (Cláudia M). O material empírico mostrou que quando o professor-tutor era enfermeiro, despertou o interesse dos alunos da medicina para a profissão o que proporcionou um novo olhar em relação a essa categoria profissional. Dessa forma, a educação interprofissional apresenta-se como uma possibilidade de mudar atitudes e percepções sobre a profissão do outro e, ainda, aumentar a confiança entre as mesmas, proporcionadas pela socialização das categorias profissionais (REEVES, 2016). Por isso há de se pensar que algumas 
ISSN 2179-6750

barreiras nas relações entre os alunos podem ser criadas ou, até mesmo, reforçadas pelo próprio professor-tutor, dificultando, assim, que a educação interprofissional e a troca de saberes entre os mesmos ocorram: No primeiro ano eu percebia o grupo mais unido. Agora no segundo, teve aquela divisão de enfermagem e medicina. [...] Então, acho que pelo jeito do professor não querer estar lá todo mundo junto, todo mundo unido pra isso, eu acho que dividiu de verdade. (Rosa E). O papel de mediador do professor-tutor ficou evidente como sendo primordial para a realização das atividades propostas nas disciplinas e aquele que por meio da educação interprofissional transcende qualquer obstáculo existente entre os cursos. Outro aspecto em relação ao professor-tutor é a empatia, identificada pelos entrevistados como uma habilidade/competência facilitadora para a realização das atividades bem como a experiência prévia em lecionar: No primeiro ano a gente já tem aquele laço com o professor, então, deixar o mesmo tutor no segundo ano, também, seria bom, porque ela já sabe até que ponto ela pode deixar a gente ir e até que ponto ela pode puxar a rédea. (Rosa E). [...] não vi diferença nenhuma por elas serem de outra área profissional [...] Agora uma coisa que influenciou é a experiência (em lecionar) (Graziella E). O professor-tutor desempenha função ímpar ao ser considerado como o indivíduo que "encanta os estudantes para que se tornem seres conscientes de seu papel enquanto aprendiz e indivíduo com responsabilidade social" (SILVA, 2011, p. 172). Outra questão a ser pontuada é a de que o professor-tutor pode proporcionar momentos de troca de saberes dos alunos entre si, dos alunos com os profissionais dos serviços de saúde, corroborando para as diversas oportunidades da educação interprofissional e da prática colaborativa. Igual a uma paciente que eu atendi e acompanhei. Ela tinha problema de memória e não sabia lidar com isso. Cheguei no Posto e falei com o meu professor e ele falou assim: 'conversa com a médica, vê até onde isso a afeta, por quê que isso acontece e depois a gente vem e conversa sobre isso com a enfermeira, também". (Rosa E) [...] você tinha que buscar, trazer e compartilhar com o grupo. Então aconteciam discussões. E no final ela sempre [...] acrescentava uma informação. [...] porque você acabava buscando o conhecimento e complementando com o que o outro trazia". (Thereza E) De acordo com Paulo Freire: "O educador já não é aquele que apenas educa, mas, o que enquanto educa, é educado em diálogo com o educando que ao ser educado também educa [...]" (FREIRE, 2011, p. 68); e, por isso, a compreensão, por parte dos professores, desse modo de ensinar e, também, da lacuna existente entre o profissional que se quer formar mediante as reais necessidades dos serviços de saúde e o preparo dado na formação desse é de extrema importância. Considerações finais Nesse sentido o papel do professor-tutor é primordial por esse ser o mediador entre a teoria e a prática e um facilitador de todo o processo de ensinoaprendizagem do aluno, e, ainda, por dar sustentação ao uso da educação interprofissional como ferramenta de ensino e potencializar uma futura prática profissional colaborativa.

Descritores: Educação superior, Relações interprofissionais, Atenção Primária à Saúde, Medicina Enfermagem 